\title{
Self-Efficacy in Coping Behaviors of Cancer Patients: Who Am I and What Can I Accomplish?
}

\section{Kanser Tanılı Hastaların Baş Etme Davranışlarında Öz-Etkililik: Ben Kimim ve Neleri Gerçekleştirebilirim?}

\begin{abstract}
Kamile Krrca $^{1} *$, Sevinç Kutlutürkan ${ }^{2}$
ABSTRACT

Cancer symptoms make patients less able to cope with their health conditions, more vulnerable to negative outcomes, and more likely to develop negative self-efficacy. Self-efficacy is one's judgment and belief in how successfully one can overcome possible future challenges. The self-efficacy theory holds that people are likely to engage in activities which they believe they can accomplish and avoid those in which they perceive themselves to be incompetent. Self-efficacy is of paramount significance for cancer patients to cope with treatment-related physical, social, and psychological problems and to adapt to new life situations. It should, therefore, be considered an integral part of well-being and success in symptom management. Nurses play a significant role in health-promoting behavior development. Nurses also manage such variables as maintaining activities of daily living, increased success rates, adaptation to change, involving family and social support mechanisms in the process, and encouraging and informing patients. Thus, nurses also support patients to increase their self-efficacy perceptions. The purpose of this review is to present the literature on the concept of self-efficacy, which is a determinant of the coping behaviors of patients with cancer.
\end{abstract}

Key words: Cancer, difficulty, coping, belief, self-efficacy, nursing

\section{ÖZET}

Kanser, bireylerde ortaya çıkardığı semptomlar nedeniyle kişinin hastalığı ile baş etme gücünü azaltmaktadır. Bu durumdaki birey, kendini daha güçsüz hissedebilmekte ve öz etkililik algısı olumsuz yönde etkilenmektedir. Öz etkililik, bireyin gelecekte karşılaşabileceği güç durumların üstesinden gelmede ne derece başarılı olabileceğine ilişkin kendi hakkındaki yargısı ve inancıdır. Öz etkililik teorisi, genellikle insanların başarmaya inandıkları şeylere girişim yaptığını, başarısız olacağına inandıklarına da teşebbüs etmeyeceğini söyler. Öz etkililik, kanser tanılı hastaların tedavi ile ilişkili fiziksel, sosyal ve psikolojik sorunlarla baş edebilmesi ve bu yeni yaşam sürecine uyum sağlanması bakımından son derece önemlidir. Öz etkililik, iyi oluş ve başarılı bir semptom yönetiminin de etkili bir bileşeni olarak düşünülmektedir. Hemşirelerin bireylerin sağlı̆̆ını geliştirmeye yönelik olumlu davranışlar edinmelerindeki rolleri de önemlidir. Hemşire ayrıca, günlük yaşam aktivitelerinin sürdürülmesi, başarma performansının artırılması, değişikliğe uyumunun sağlanması, aile/sosyal destek mekanizmalarının sürece dâhil edilmesi, cesaretlendirme ve bilgi eksikliğinin giderilmesi gibi pek çok değişkeni de yönetmektedir. Böylelikle hemşireler hastaların öz etkililik algılarının yükseltilmesine destek olurlar. Bu derlemenin amacı kanser tanılı hastaların baş etme davranışlarının bir belirleyicisi olan öz etkililik kavramına ilişkin literatür bilgilerinin sunulmasidir.

Anahtar kelimeler: Kanser, güçlük, baş etme, inanç, öz etkililik, hemşirelik

Received / Geliş tarihi: 29.05.2020, Accepted / Kabul tarihi: 09.04.2021

${ }^{1}$ Kirıkkale University, Faculty of Health Sciences, Nursing Department, KIRIKKALE (ORCID: 0000-0001-7019-6107)

${ }^{2}$ Ankara University, Faculty of Nursing, ANKARA (ORCID: 0000-0002-3230-0775)

*Address for Correspondence / Yazışma Adresi: Kırıkkale Sağlık Yerleşkesi Fabrikalar Mah. İbni Sina Cad. No:12 (Arpalık Çukuru Mevki) Merkez/ Kırıkkale-TÜRKIYE

Tel: +90-318-357 3738

E-posta: kamilekirca@kku.edu.tr

Kirca K, Kutluturkan S. Self-Efficacy in Coping Behaviors of Cancer Patients: Who Am I and What Can I Accomplish?. TJFMPC, 2021;15(3): 610-621

DoI: $10.21763 /$ tjfmpc.744412 


\section{INTRODUCTION}

Perceived self-efficacy is defined as people's beliefs about their capabilities to produce designated levels of performance that exercise influence over events that affect their lives. Self-efficacy beliefs determine how people feel, think, motivate themselves, and behave. Such beliefs produce these diverse effects through four major processes. They include cognitive, motivational, affective, and selection processes. A strong sense of efficacy enhances human accomplishment and personal well-being in many ways. People with high assurance in their capabilities approach difficult tasks as challenges to be mastered rather than as threats to be avoided. Such an efficacious outlook fosters intrinsic interest and deep engrossment in activities. They set themselves challenging goals and maintain a strong commitment to them. They heighten and sustain their efforts in the face of failure. They quickly recover their sense of efficacy after failures or setbacks. They attribute failure to insufficient effort or deficient knowledge and skills which are acquirable. They approach threatening situations with assurance that they can exercise control over them. Such an efficacious outlook produces personal accomplishments, reduces stress, and lowers vulnerability to depression. ${ }^{1}$

Self-efficacy is directly related to health behavior, but it also affects health behaviors indirectly through its impact on goals. Self-efficacy influences the challenges that people take on as well as how high they set their goals (e.g., "I intend to reduce my smoking," or "I intend to quit smoking altogether"). Individuals with strong self-efficacy select more challenging goals. ${ }^{2,3}$ Self-efficacy plays a key role not only in health-promoting behaviors but also in the successful self-management of chronic diseases. Only patients who make healthy lifestyle choices and actively engage in healthcare services can effectively manage their health conditions. ${ }^{1,2}$ Personality traits, chronic conditions, disease perception, and lack of social support may negatively affect self-efficacy. ${ }^{7-9}$

Psychologist Albert Bandura was the first to coin the term "self-efficacy" (1977) and to define it as "one's belief in one's ability to overcome problems and one's perception or judgment of one's capacity to control events, no matter one's level of knowledge", 5,7 According to Bandura (2002), selfefficacy can be improved. ${ }^{8}$ As a basic concept of social learning theory, self-efficacy is one's beliefs about one's capabilities to organize and execute the courses of action required to successfully address problems. Self-efficacy has a great impact on perceptions, motivation, and performance and enables the individual to act after they compare their possible performance and current capacity. Self- efficacy refers to the individual's belief in how well they can cope with difficulties. In short, self-efficacy is self-knowledge (Who am I and what can I accomplish? / What can I not accomplish?). ${ }^{9,10}$

Bandura's Social Learning Theory is based on six core principles, which are as follows: $:^{5,9,11}$

1. Mutual Determination: Learning involves three main factors; individual, environment, and behavior. On one corner of the triangle is the individual's characteristics, personality traits, views, expectations, and beliefs. On another corner is behavior, which affects one's decisions and causes others to react to one. On the third corner is the environment. On the one hand, environmental factors affect one's decisions and, on the other hand, events shape how one should behave.

2. Symbolization: According to Bandura, what people construct in their minds represent what they see in the world, allowing them to use language to think and express what they think. They use past events to think about the future. They use those symbols in their minds, this time to evaluate their future expectations, concerns, and hopes.

3. Insight: People are capable of developing ideas and symbols to code their experiences in their minds and to make plans. They set goals and make plans for the future to meet their expectations and develop a model for how they should react to other people's possible actions in the future. In short, thought precedes action.

4. Indirect Learning: People observe others to learn about their actions and the consequences of those actions. People also learn from their actions and their consequences; however, it puts a limit on their learning capacity. Learning from others' experiences, on the other hand, improves learning capacity and rate

5. Self-regulation: Social learning theory holds that people have the potential for self-modeling because they can control and regulate their own lives. They adjust their lives not for others but themselves in all personal affairs, such as eating habits, status and mode of working, lifestyles, and recreation and entertainment choices. Moreover, they operate according to their standards and motivations in an activity or project. In other words, people are responsible for their actions.

6. Self-judgment is the last and most important principle of social learning theory. People think about themselves and express what they think. After putting their ideas and thoughts into action, they think about their consequences and pass judgement on their actions, which refers to the concept of self-efficacy 
People with high self-efficacy know what actions to take, how much effort to put in, how to cope with difficulties, and how concerned and confident to be. ${ }^{10}$ Table 1 shows the characteristics of people with high and low self-efficacy.

Table 1.Characteristics of People with High and Low Self-Efficacy ${ }^{11}$

\begin{tabular}{|l|l|}
\hline $\begin{array}{l}\text { Characteristics of } \\
\text { People with High Self- } \\
\text { Efficacy }\end{array}$ & $\begin{array}{l}\text { Characteristics of } \\
\text { People with Low Self- } \\
\text { Efficacy }\end{array}$ \\
\hline -Coping with & -Failure to cope with \\
complicated situations & $\begin{array}{l}\text { complicated situations } \\
\text {-Unhappiness and } \\
\text { problems Overcoming } \\
\text {-Being patient in life } \\
\text {-Believing in their } \\
\text { potential academic } \\
\text {-High } \\
\text { performance } \\
\text {-Thriving } \\
\text { professional life in solving problems } \\
\text { - Feeling incompetent } \\
\text { if failed at the first } \\
\text { attempt } \\
\text {-Believing that their } \\
\text { effort will not make } \\
\text { any difference }\end{array}$ \\
\hline
\end{tabular}

Certain factors affect people's beliefs that they are capable of coping with problems that they face. ${ }^{5}$ Bandura argues that self-efficacy has four sources, which are:

1. Performance Accomplishments: This is what people learn from their successful or failed actions.

2. Vicarious Experience: Successful or failed actions of similar others affect people's judgment of whether they too can perform those actions or not.

3. Social Persuasion: Encouragement or discouragement and positive and negative feedback affect self-efficacy to varying degrees.

4. Physiological and Emotional States: The expectation of accomplishing or failing a task affects self-efficacy. .,9-11

Self-efficacy, which is an internal state, is the combination of self-competence, sense of success, self-respect, and self-worth. Self-efficacy development depends on one's approach to the three factors below:

1. Expectation of competence: Perceiving a task as easy, hard or very hard and making an assessment of the possibility of accomplishment or failure

2. Generalization: Applying a new behavior to similar situations and using it when necessary

3. Reinforcement: One's strong belief that one can exhibit a behavior. Those with such strong beliefs do not change their minds even when they fail. However, failures make one stronger. ${ }^{5,9-11}$

\section{The Effects of Self-Efficacy on Actions}

Self-efficacy affects actions in different ways.

1. Behavior Choice: People's self-efficacy affects how they behave in certain situations. People are likely to avoid tasks they believe exceed their capabilities and engage in tasks they believe they can accomplish.

2. Effort and Continuity: The higher the selfefficacy, the more and continuous the effort.

3. Ways of Thought and Emotional Responses: People with low self-efficacy think that situations, events, and problems are harder than they are, causing them to suffer from stress and to approach problems from a narrow perspective. However, those with high self-efficacy thrive on challenges and focus their attention and effort on them.

4. Being the Developer Rather than the Reporter of Behavior: People with high self-efficacy think, feel, and act differently from those with low self-efficacy. The former shape their future instead of foretelling about it or their behavior. . $^{5,10,11}$

A large body of related research supports the predictive value that self-efficacy has on health behavior change. Self-efficacy either has a significant direct effect on behaviors or it becomes a mediator between other psychological variables to health behaviors. ${ }^{12-17}$ Given the increasing prevalence of chronic illnesses and their complications, supporting and empowering chronically ill patients seems crucial. Self-efficacy is considered as a predictor for empowerment. ${ }^{18}$ Due to their chronic nature, these conditions cause different psychosocial problems, endanger patients' identities, change their roles and lifestyles, and make them unable to fulfill their needs. Therefore, patients with chronic diseases need extensive care, support, and empowerment-based services in order to cope with their diseases. By definition, empowerment is "the process that helps people gain control over their own lives and increases their capacity to act on issues that they define as important". It is associated with greater confidence, autonomy, self-efficacy, and self-determination in doing activities of daily living as well as self-care activities. ${ }^{18-20}$ Self-efficacy is a mediator between knowledge and self-care and exploring strategies to boost self-efficacy will improve health outcomes in patients navigating chronic diseases. ${ }^{21,22}$

\section{Cancer, Self-efficacy, and Nursing}


Cancer is a chronic disease with high mortality and morbidity. Effective coping strategies throughout diagnosis, treatment, and rehabilitation require high self-efficacy because it predicts high intention to quit smoking, active participation in cancer screening programs, adherence to diagnosis and treatment, and adopting health-promoting behaviors. However, cancer patients need more support to build selfconfidence, learn stress management, and develop positive attitudes, self-care behaviors, and functional status. Especially patients with advanced cancer need more support to build self-confidence for selfcare, activities of daily living, and effective symptom management. ${ }^{6}$

Adaptation or psychosocial adjustment to cancer involves coping with pain, solving problems, and controlling disease events. Cancer patients go through changes in their physical appearance, and have to deal with stigmatization, therapeutic difficulties, and side effects, and have to adjust to life after treatment. Such challenges lead to great changes in patients' lives and put them in a position where they have to adopt new copingstrategies. ${ }^{23,24}$ Distorted self-perception of body image is often associated with mental problems, such as reduced self-confidence. Given the high incidence of cancer, individuals should be aware of their perceptions in life, not only for early diagnosis and appropriate treatment but also to provide a good quality of life index. ${ }^{25-27}$

Nurses addressed self-efficacy and integrated it into nursing models many years ago. The "Health Promotion Model" (HPM) proposed by Nola J Pender (1982) focuses on promoting health and improving health behaviors. The HPM is based on Social Learning Theory and addresses the cognitive processes that affect health-promoting behaviors. The HPM explains health-promoting factors and causal mechanisms and argues that selfefficacy plays a key role in initiating and maintaining health-promoting behaviors. It addresses healthpromoting behaviors under three factors; cognitive perceptual, changeable, and behavior triggering. It highlights the significance of participating in healthcare activities and maintains that perceived self-efficacy and health state and recognizing the benefits of health-promoting behaviors can affect health for the better or worse. ${ }^{28}$ Pender considers healthy life to be a component of health promotion. Health-promoting behaviors are those that improve well-being and allow for self-realization. According to Pender, health-promoting behaviors involve selfrealization, health responsibility, exercise, healthy diet, interpersonal support, and stress management. The HPM provides a holistic approach by taking personal background and self-perception into account. $^{28,29}$
Another model that examines the concept of self-efficacy is The "Health Belief Model" (HBM). The HBM is one of the many models in health education that can be used as the basis for health promotion programs. The HBM is a psychological health behavior change model which was developed to explain and predict health-related behaviors, in relation to health services. The health belief model was developed in the 1950s by American social psychologists at Public Health Service and is considered one of the common and most used theories in health behavior studies. The health belief model main concerned with; people's beliefs about health problems, perceived benefits and barriers to action, and self-efficacy that explain the engagement or the lack of engagement in health-promoting behavior. ${ }^{30}$ The HBM is a great tool for nurses, offering them a theoretical framework for helping their patients prevent chronic disease or, if the disease is present, improve quality of life. Nurses can use this model to clarify patients' perceptions of risk and why they behave in a harmful way; this enables nurses to apply strategies that influence patients to make healthy lifestyle changes. Patients' perceptions can be affected by age, sex, and personality. Consider your patients who are overweight and diabetic or those who have high blood pressure and eat processed convenience foods high in sodium..$^{28-30}$

For health promotion, educators are the most suitable people to help patients and also nurses as easily accessible consultants. As for health promotion focusing on behavior change, patients should be encouraged to develop and maintain positive health behaviors. Nurses, who play a key role in healthcare for a healthy society, assume the roles of caregivers, educators, consultants, leaders, activists/proactive change agents, advocates, communicators, care coordinators, role models, and researchers in health promotion. Someone who believes that they can achieve a positive result is likely to take action and take control of their life. Self-efficacy has a great impact on behavior. Therefore, nurses should exploit the interchangeability and affectability characteristics of self-efficacy and should provide interventions to help patients develop self-efficacy and strengthen their perceptions of their accomplishments for behavior change. ${ }^{28,29}$ Nurses play a significant role in health-promoting behavior development. For effective care, they should approach their patients from all perspectives and evaluate their self-efficacy before planning care. ${ }^{31}$ Nurses also manage such variables as maintaining activities of daily living, increased success rates, adaptation to change, involving family and social support mechanisms in the process, and encouraging and informing patients. Therefore, they are responsible for helping patients develop self-efficacy and improve their quality of life by maximizing their capacity. To that end, they 
should manage patient care and treatment, enhance functional self-actualization, solve problems, make sure that patients adapt to new situations, and involve family members, and most importantly, patients in care. ${ }^{32}$ The common objective of healthcare professionals is to make sure that patients are at their best physically, cognitively, psychologically, emotionally, and socially. Nurses are the healthcare professionals who can evaluate self-efficacy best and can help patients improve it and spend the most time with them. In the literature, it is seen that there are not enough studies evaluating nursing interventions in improving self-efficacy in cancer patients. Studies mostly relate to other chronic diseases. ${ }^{19,2123,26-29,32-37}$

Chronic diseases affect self-efficacy. Cancer in particular results in low motivation and low self-efficacy. ${ }^{29}$ Self-efficacy can be improved. ${ }^{33}$ In cancer patients, high self-efficacy is positively associated with the behavioral effort to perform challenging self-care tasks in some way to improve their health conditions..$^{35,38}$ Numerous concurrent symptoms of cancer negatively affect patients and cause discontinuities and low success in treatment, and unexpected treatment outcomes. ${ }^{39,40}$ In such cases, one symptom leads to another or makes it worse. Therefore, symptom management in cancer patients should focus primarily on well-being, coping, and quality of life.

Table 2 presents the characteristics of some researches on self-efficacy in patients diagnosed with cancer. In these studies, the results regarding the self-efficacy levels of the patients and the effectiveness of the attempts to increase their selfefficacy levels were evaluated. The results of this study show that the self-efficacy level and quality of life of cancer patients are closely related. In addition, the level of self-efficacy increases as emotional wellbeing and health literacy increase. Psychological interventions also positively affect the level of selfefficacy. The fear that the disease will progress decreases the level of self-efficacy. ${ }^{26,36,41,53,56}$

\section{CONCLUSION}

Cancer diagnosis, medical procedures, and treatment are stressful situations for patients with cancer. Research in the psycho-oncology field indicates that self-efficacy is an important factor in patients' capability to manage situations related to their cancer diagnosis and treatment. Self-efficacy is an important component of well-being and successful symptom management. Cancer patients with high self-beliefs about their capacity to perform the behaviors necessary for self-efficacy are more likely to participate in effective symptom management strategies, which make it easier for them to adapt to the disease and treatment. In conclusion, nurses should determine patients' self-efficacy to achieve effective symptom management during care. 
Table 2.Characteristics of some researches on self-efficacy in patients diagnosed with cancer (2010-2020)

\begin{tabular}{|c|c|c|c|}
\hline $\begin{array}{l}\text { Authors and year } \\
\text { of publication }\end{array}$ & Research design & Method & Results-Conclusion \\
\hline \begin{tabular}{|l|} 
Özkaraman et \\
$\mathrm{al} .^{36}(2019)$
\end{tabular} & $\begin{array}{l}\text { Cross-sectional, } \\
\text { descriptive study }\end{array}$ & $\begin{array}{l}\text { Aim: To assess the effect of health literacy on cancer patients' } \\
\text { self-efficacy and quality of life. } \\
\text { Sample size: } n=111 \\
\text { Self-efficacy measure: The Self-Efficacy to Manage Chronic } \\
\text { Disease Scale }\end{array}$ & $\begin{array}{l}\text { A statistically significant positive relationship was found between the Self- } \\
\text { Efficacy to Manage Chronic Disease Scale and the functional }(p<0.001) \text { and } \\
\text { general health }(p<0.001) \text { subscales while a statistically significant negative } \\
\text { relationship }(p<0.001) \text { was found between the Self-Efficacy to Manage } \\
\text { Chronic Disease Scale and the symptom subscale.Increased literacy levels } \\
\text { were found in cancer patients and it helped in improving in their self-efficacy, } \\
\text { general health and functional status. }\end{array}$ \\
\hline $\begin{array}{l}\text { Noruzi Zamenjani } \\
\text { et al., }{ }^{26} \text { (2019) }\end{array}$ & Experimental study & $\begin{array}{l}\text { Aim: To determine the effect of relaxation techniques on self- } \\
\text { efficacy of patients suffering from cancer } \\
\text { Sample size: } n=80 \text {, Experimental group }=40 \text {, Control group }=40 t \\
\text { Self-efficacy measure: Strategies Used by People to Promote } \\
\text { Health questionnaires } \\
\text { Intervention: Experimental group: Progressive relaxation } \\
\text { techniques ( } 30 \text { minutes } 2 \text { days a day), Control group: Clinical } \\
\text { routine care }\end{array}$ & $\begin{array}{l}\text { A statistically significant difference was observed between the mean self- } \\
\text { efficacy indices in the experimental group }(\mathrm{p}=0.001) \text {. Progressive relaxation } \\
\text { techniques are effective in increasing self-efficacy of cancer patients }\end{array}$ \\
\hline $\begin{array}{l}\text { Merluzzi et al., }{ }^{25} \\
(2019)\end{array}$ & $\begin{array}{l}\text { A Meta-Analysis of } \\
\text { Randomized Controlled } \\
\text { Trials }\end{array}$ & $\begin{array}{l}\text { Aim: The current meta-analysis investigated the impact of } \\
\text { psychological interventions on self-efficacy expectations for a } \\
\text { variety of health behaviors among cancer patients. } \\
\text { Sample size: } 79 \text { RCTs, } 223 \text { effect sizes, and } 8678 \text { participants }\end{array}$ & $\begin{array}{l}\text { The results establish the impact of psychological interventions on self-efficacy } \\
\text { expectations as comparable in effect size with commonly reported outcomes } \\
\text { (distress, fatigue, pain). Additionally, the result that in-person interventions } \\
\text { achieved the largest effect is supported by the social learning theory and could } \\
\text { inform research related to the development and evaluation of interventions. }\end{array}$ \\
\hline $\begin{array}{l}\text { Chen et al., }{ }^{41} \\
(2018)\end{array}$ & Prospective kohort & $\begin{array}{l}\text { Aim: To investigate the relationship between self-efficacy, } \\
\text { cancer-related fatigue, and quality of life in patients with } \\
\text { resected lung cancer. } \\
\text { Sample size: } n=452 \\
\text { Self-efficacy measure: General Self-Efficacy Scale }\end{array}$ & $\begin{array}{l}\text { The results showed self-efficacy has direct and indirect effect on quality of life } \\
\text { in patients with resected lung cancer. Furthermore, cancer-related fatigue, as } \\
\text { mediated variables, can mediate the relationship between self-efficacy and } \\
\text { quality of life. }\end{array}$ \\
\hline \begin{tabular}{|lll} 
Chirico & et & al., \\
$(2017)$ & & \\
\end{tabular} & A Meta-analytic review & $\begin{array}{l}\text { Aim: The following general questions provide a framework for } \\
\text { this research: } 1 \text {. Is self-efficacy for coping with cancer related to } \\
\text { distress and quality of life of a cancer patient?. 2. Do self- } \\
\text { efficacy for coping with cancer and the target psychological } \\
\text { outcomes (i.e., distress and quality of life) change in } \\
\text { longitudinal studies, with or without intervention? } \\
\text { Sample size: } n=47 \text { article }\end{array}$ & $\begin{array}{l}\text { Result showed an inverse relationship between self-efficacy for coping with } \\
\text { cancer and distress, and a positive relationship between self-efficacy for coping } \\
\text { with cancer and Quality of Life, both with a large effect size. }\end{array}$ \\
\hline \begin{tabular}{|l} 
Adams et al., \\
$(2016)$
\end{tabular} & Cross-sectional & $\begin{array}{l}\text { Aim: To examine the relationship between social constraints } \\
\text { and physical symptom among breast cancer survivors }\end{array}$ & $\begin{array}{l}\text { Findings are consistent with social cognitive processing theory and suggest that } \\
\text { symptom management interventions may be enhanced by addressing the }\end{array}$ \\
\hline
\end{tabular}




\begin{tabular}{|c|c|c|c|}
\hline & & $\begin{array}{l}\text { Sample size: } \mathrm{n}=1127 \\
\text { Self-efficacy measure: Breast Cancer Self-Efficacy Scale }\end{array}$ & $\begin{array}{l}\text { impact of social constraints from survivors' partners and healthcare providers } \\
\text { on their coping and self-efficacy. }\end{array}$ \\
\hline $\begin{array}{l}\text { Liang et al., } \\
(2016)\end{array}$ & Cross-sectional & $\begin{array}{l}\text { Aim: To determine relationship between symptom distress and } \\
\text { quality of life and to examine a mediating role of } \\
\text { symptommanagement self-efficacy between symptom distress } \\
\text { and quality of life } \\
\text { Sample size: } n=201 \\
\text { Self-efficacy measure: Symptom Management Self-Efficacy } \\
\text { Scale Breast Cancer (SMSES-BC }\end{array}$ & $\begin{array}{l}\text { Symptom-management self-efficacy mediated the association between } \\
\text { symptom distress and global QOL, functional QOL, and symptom QOL. The } \\
\text { lower symptom distress that patients experienced was indirectly associated } \\
\text { with better QOL through higher self-efficacy. }\end{array}$ \\
\hline $\begin{array}{l}\text { Nejad et al., } \\
(2015)\end{array}$ & Cross-sectional & $\begin{array}{l}\text { Aim: To determine the level of cancer-related self-efficacy in } \\
\text { Iranian women with breast cancer } \\
\text { Sample size: } n=91 \\
\text { Self-efficacy measure: Cancer Behavior Inventory (CBI) }\end{array}$ & $\begin{array}{l}\text { The sustained cancer-related positive attitude had, in total, the highest mean } \\
\text { score of } 7 \text { subscales of cancer behavior inventory and the seeking of social } \\
\text { support had the least mean score. Only Patient's education and the time of } \\
\text { cancer diagnosis were associated with self-efficacy of Iranian women in } \\
\text { relation to cancer. }\end{array}$ \\
\hline $\begin{array}{l}\text { Liang et al., } \\
(2015)\end{array}$ & Cross-sectional & $\begin{array}{l}\text { Aim: To develop and evaluate the Psychometric of the } \\
\text { SymptomManagement Self-Efficacy Scale Breast Cancer } \\
\text { Sample size: } n=152 \\
\text { Self-efficacy measure: SymptomManagement Self-Efficacy } \\
\text { Scale Breast Cancer (SMSES-BC) related to chemotherapy. }\end{array}$ & $\begin{array}{l}\text { Three factors (managing chemotherapy-related symptoms, acquiring problem } \\
\text { solving, and managing emotional and interpersonal disturbances) were } \\
\text { identified from exploratory factor analysis. }\end{array}$ \\
\hline $\begin{array}{l}\text { Zhang et al., } \\
(2015)\end{array}$ & $\begin{array}{l}\text { Cross-Sectional } \\
\text { Descriptive }\end{array}$ & $\begin{array}{l}\text { Aim:To describe the levels of uncertainty, self-efficacy, and } \\
\text { self-care behavior in Chinese women receiving chemotherapy } \\
\text { for breast cancer and to determine if self-efficacy mediates the } \\
\text { relationship between uncertainty and self-care behavior. } \\
\text { Sample size: } n=152 \\
\text { Self-efficacy measure: General Self-Efficacy Scale (GSE) }\end{array}$ & $\begin{array}{l}\text { Two demographic variables which decrease self-efficacy in breath cancer } \\
\text { were: young age and no college education. Relationship between uncertainly } \\
\text { and SE was not statistically significant. Both SE and uncertainty independently } \\
\text { predicted self-care behavior. SE positively correlated with self-care behavior } \\
\text { when controlling effect of uncertainty. }\end{array}$ \\
\hline $\begin{array}{l}\text { Chang et al., } \\
(2014)\end{array}$ & $\begin{array}{l}\text { Descriptive, } \\
\text { Longitudinal }\end{array}$ & $\begin{array}{l}\text { Aim: To examine the differences between women who delay } \\
\text { and women who did not delay seeking a cancer diagnosis, and } \\
\text { key factors predicting self-efficacy over time among women } \\
\text { with newly-diagnosed breast cancer. } \\
\text { Sample size: } n=80 \\
\text { Self-efficacy measure: Self-Efficacy to Maintain Quality of } \\
\text { Life Scale (SEQOL) }\end{array}$ & $\begin{array}{l}\text { Stage of cancer, trait extroversion/neuroticism and spiritual support were } \\
\text { significantly different between groups }(p<0.05) \text {. Subjects who did not delay } \\
(\beta=-1.613, p<0.05) \text {, and time that histology results were provided ( } \beta=-2.4333 \text {, } \\
p<0.001) \text { had a significantly predicted negative change in self-efficacy } \\
\text { compared to the group that delayed. Hope at the first clinic visit contributed to } \\
\text { the change in self-efficacy over time }(\beta=0.391, p<0.001) \text {. Personal factors } \\
\text { affecting a woman's delay in obtaining medical assessment of breast cancer } \\
\text { confirmation. Hope impacts self-efficacy of women with suspected breast } \\
\text { cancer and interventions to enhance hope during the early stages of breast } \\
\text { cancer evaluation require further study. }\end{array}$ \\
\hline $\begin{array}{l}\text { Shelby et al., } \\
(2014)\end{array}$ & Cross-Sectional & $\begin{array}{l}\text { Aim: This study examined the relationships between physical } \\
\text { symptoms, self-efficacy for coping with symptoms, and }\end{array}$ & $\begin{array}{l}\text { Older women had higher SE. Women who had lower SE showed higher } \\
\text { physical symptoms. Interaction between physical symptoms and SE was } \\
\text { significant. Patients who had lower SE reported that physical symptoms were }\end{array}$ \\
\hline
\end{tabular}




\begin{tabular}{|c|c|c|}
\hline & & \begin{tabular}{|l|l|} 
functional, emotional, and social well-being in women who associated with lower functional well-being $(\mathrm{P}<0.001)$. Physical symptoms \\
were taking adjuvant endocrine therapy for breast cancer. & did not correlate with well-being among women with high SE. SE for coping \\
Sample size: $\mathrm{n}=120$ & with symptoms had moderated relationship between physical symptoms and \\
Self-efficacy measure: Perceived Self-Efficacy & emotional well-being.
\end{tabular} \\
\hline $\begin{array}{l}\text { Griggs et al., } \\
(2014)\end{array}$ & Cross-sectional & $\begin{array}{l}\text { Aim: To characterize factors associated with first cycle Patient self-efficacy did not correlate with chemotherapy. Ethnicity or patient } \\
\text { chemotherapy dose selection in a multi-ethnic sample of low-self-efficacy (in communicating with physician's team) did not effect on } \\
\text { income women receiving chemotherapy through the Breast and receiving adjuvant chemotherapy. } \\
\text { Cervical Cancer Prevention Treatment Program (BCCPT) and } \\
\text { to investigate the impact of Hispanic ethnicity and patient self- } \\
\text { efficacy on adjuvant chemotherapy dose selection.Sample size: } \\
\text { n=397 } \\
\text { Self-efficacy measure: Perceived efficacy in patient-physician } \\
\text { interactions (PEPPI) }\end{array}$ \\
\hline $\begin{array}{l}\text { García-Jimenez et } \\
\text { al., }{ }^{51}(2014)\end{array}$ & $\begin{array}{l}\text { Cross-sectional } \\
\text { telephone survey }\end{array}$ & $\begin{array}{l}\text { Aim: To examine the relation between cancer self-efficacy and Higher cancer self-efficacy and greater inner peace had significant correlation } \\
\text { spiritual wellbeing with acculturation, and study the mediating with better self-rated health. Cancer self-efficacy impacted on the self-rated } \\
\text { role in the relationship between acculturation and Self-rated health by the means of spiritual well-being related to inner peace and meaning } \\
\text { health. } \\
\text { in one's life. } \\
\text { Sample size: } n=333 \\
\text { Self-efficacy measure: Cancer self-efficacy (CSE) }\end{array}$ \\
\hline $\begin{array}{l}\text { Melchior et al., }{ }^{52} \\
(2013)\end{array}$ & Cross-sectional & \begin{tabular}{|l|l|} 
Aim: To investigate fear of disease progression (FoP) during Findings that low SE is associated with high FoP can help to improve the \\
the year following diagnosis of breast cancer and its association & treatment of dysfunctional fears in breast cancer patients. As FoP changes only \\
with general self-efficacy (SE) & slightly over time, treatment to enhance SE and reduce FoP should be initiated \\
Sample size: $n=118$ & soon after disease disclosure. \\
Self-efficacy measure: General Self Efficacy Scale &
\end{tabular} \\
\hline $\begin{array}{l}\text { Champion et al., }{ }^{53} \\
(2013)\end{array}$ & Cross-sectional & 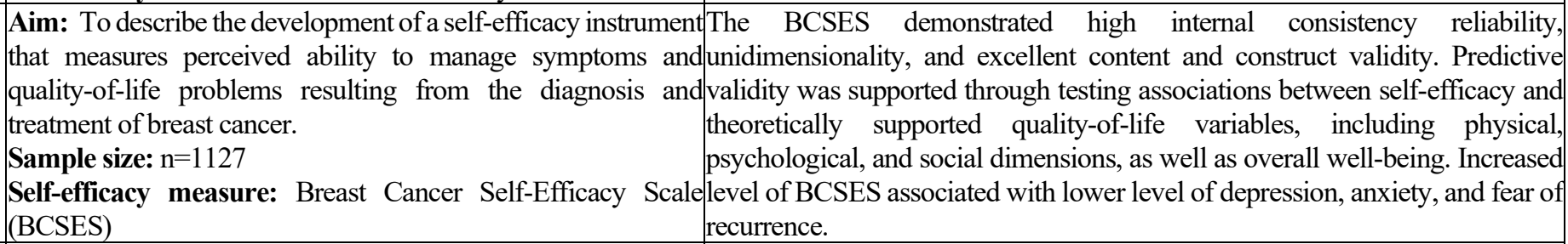 \\
\hline Ziner et al., ${ }^{54}(2012)$ & Cross-sectional & $\begin{array}{l}\text { Aim: To determine the effect that age at diagnosis has on fear } \begin{array}{l}\text { Survivors diagnosed at a younger age had significantly higher fear of } \\
\text { of breast cancer recurrence and to identify the predictors of fear } \\
\text { of recurrence, as well as health, role, womanhood, death, and parenting worries. } \\
\text { Sample size: } n=1128 \\
\text { Self-efficacy measure: Breast Cancer Survivor Self-Efficacy } \\
\text { Scale }\end{array} \quad \begin{array}{l}\text { explained significant variance in fear of recurrence and breast cancer survivor } \\
\text { of variables on fear of recurrence. The findings suggest that breast cancer } \\
\text { survivor self-efficacy may have a protective effect for survivors who are }\end{array}\end{array}$ \\
\hline
\end{tabular}




\begin{tabular}{|c|c|c|c|}
\hline & & & $\begin{array}{l}\text { younger at diagnosis and have higher perceived risk of recurrence, higher trait } \\
\text { anxiety, and more breast cancer reminders. }\end{array}$ \\
\hline Lam et al., ${ }^{55}$ (2012) & Qualitative interview & $\begin{array}{l}\text { Aim: To evaluate the relationship between self-efficacy and } \\
\text { access to postmastectomy breast reconstruction (PMBR) } \\
\text { information. } \\
\text { Sample size: } n=10 \\
\text { Self-efficacy measure: Modified Stanford Self-Efficacy Scale } \\
\text { And Semi-structured qualitative interview }\end{array}$ & $\begin{array}{l}\text { Two main access to information themes were identified from the patient } \\
\text { qualitative data: theme A - difficulty initiating the PMBR discussion; and } \\
\text { theme B - perceived lack of access to PMBR information with the sub-themes } \\
\text { of timing, modality, quantity and content of resources. All respondents } \\
\text { expressed their concern over the absence of a standardized process for initiating } \\
\text { the dialogue of PMBR. Patients also reported that credible and easily accessible } \\
\text { information was not routinely available and expressed a desire to hear about } \\
\text { their PMBR options early in the decision-making process. }\end{array}$ \\
\hline $\begin{array}{l}\text { Rottmann et al., }{ }^{56} \\
(2010)\end{array}$ & Longitudinal & $\begin{array}{l}\text { Aim: To examine the role of perceived self-efficacy in } \\
\text { predicting breast cancer patients' emotional, physical and social } \\
\text { well-being and to study the role of mental adjustment styles in } \\
\text { the relation } \\
\text { Sample size: } \mathrm{n}=684 \\
\text { Self-efficacy measure: Danish version of the general self- } \\
\text { efficacy (GSE) scale }\end{array}$ & $\begin{array}{l}\text { Greater self-efficacy at baseline was associated with emotional well-being after } \\
12 \text { months. Fighting spirit, anxious preoccupation and helplessness- } \\
\text { hopelessness partly mediated the effect of self-efficacy, but self-efficacy also } \\
\text { had a direct effect on emotional functioning. No association was found } \\
\text { between self-efficacy and physical and social well-being. Significant } \\
\text { associations were observed between self-efficacy and education and time since } \\
\text { diagnosis and also between well-being and age, education, relapse and time } \\
\text { since diagnosis. Self-efficacy was a significant predictor of an active } \\
\text { adjustment style and emotional well-being in breast cancer patients. }\end{array}$ \\
\hline $\begin{array}{l}\text { Mosher et al., } \\
(2010)\end{array}$ & Cross-Sectional & $\begin{array}{l}\text { Aim: This study examined the interrelations of self-efficacy for } \\
\text { coping with cancer, perceived barriers to pain management, } t \\
\text { distress, and pain outcomes in a multiethnic sample of breast } \\
\text { cancer patients. } \\
\text { Sample size: } \mathrm{n}=87 \\
\text { Self-efficacy measure: Cancer Behavior Inventory }(\mathrm{CBI})\end{array}$ & $\begin{array}{l}\text { Greater self-efficacy for coping with cancer was associated with older age, less } \\
\text { time since diagnosis, and less distress. In addition, less self-efficacy for seeking } \\
\text { and understanding medical information, Spanish language preference, and } \\
\text { greater distress predicted greater barriers to pain management. Average pain } \\
\text { severity was higher among Spanish-speaking individuals and those with lower } \\
\text { incomes.. }\end{array}$ \\
\hline
\end{tabular}




\section{REFERENCES}

1. Bandura A. Self-efficacy. In V. S. Ramachaudran (Ed.), Encyclopedia of human behavior. New York: Academic Press. (Reprinted in H. Friedman [Ed.], Encyclopedia of mental health. San Diego: Academic Press, 1998) 1994.p.71-81.

2. Schwarzer R, Luszczynska A, Ziegelmann JP, Scholz U, Lippke S. Social-cognitive predictors of physical exercise adherence: three longitudinal studies in rehabilitation. Health Psychology 2008; 27(1S): 54-63.

3. Sheeran P, Maki A, Montanaro E, AvishaiYitshak A, Bryan A, Klein WM, Miles E, Rothman AJ. The impact of changing attitudes, norms, and self-efficacy on health-related intentions and behavior: A meta-analysis. Health Psychol 2016;35(11):1178-1188.

4. Gallagher R, Donoghue J, Chenoweth L, SteinParbury J. Self-management in older patients with chronic illness. International Journal of Nursing Practice 2008;14(5),373-382.

5. Filiz SB. (Editör). Öğrenme ve öğretme kuram ve yaklaşımları. 2.Baskı, Ankara: Pegem Akademi 2013,88-94.

6. Akın S, Guner CK. Determinants of fatigue, self-efficacy, and quality of life of cancer patients during chemotherapy: A study from Turkey. Journal of Nursing Science 2017;3(4),17-26.

7. Aksayan S, Gözüm S. Olumlu sağlık davranışlarının başlatılması ve sürdürülmesinde öz-etkililik (kendini etkileme) algısının önemi. Cumhuriyet Üniversitesi Hemşirelik Yüksek Okulu Dergisi 1998;2:35-42.

8. Bandura A. Social cognitive theory in culturel context. Oxford:Oxford University Press 2002,212-213.

9. Gündüz B ve Çapri B. (Editörler). Eğitim psikolojisi. Adana: Karahan Kitabevi 2013, 269-275.

10. Aydın B, Akbağ M, Tuzcuoğlu S, Yaycı L, A ğır M. Eğitim psikolojisi. Ankara: Nobel Yayınevi 2014.p.248-250.

11. Yeşilyaprak B. Eğitim psikolojisi. (12.Bask1), Ankara: Pegem Akademi. 2014.p. 255-260.

12. Baldwin AS, Rothman AJ, Hertel AW, Linde JA, Jeffery RW, Finch EA, Lando HA. Specifying the determinants of the initiation and maintenance of behavior change: an examination of self-efficacy, satisfaction, and smoking cessation. Health Psychol 2006;25(5):626-34.

13. Hendriksen ES, Pettifor A, Lee SJ, Coates TJ, Rees HV. Predictors of condom use among young adults in South Africa: the Reproductive Health and HIV Research Unit National Youth Survey. Am J Public Health 2007;97(7):1241-8.
14. Oei TP, Burrow T. Alcohol expectancy and drinking refusal self-efficacy: a test of specificity theory. Addict Behav 2000;25(4):499-507.

15. Scholz U, Sniehotta FF, Schwarzer R. Predicting physical exercise in cardiac rehabilitation: The role of phase-specific selfefficacy beliefs. Journal of Sport and Exercise Psychology 2005;27(2):135-151.

16. Darker CD, French DP, Eves FF, Sniehotta FF. An intervention to promote walking amongst the general population based on an 'extended' theory of planned behaviour: a waiting list randomised controlled trial. Psychol Health 2010;25(1):71-88.

17. Isa A, Muhamad NA, Mustapha N, Abdul Mutalip MH, Lodz NA, Royali SM, Baharin MF, et al. Association between self-efficacy and health behaviour in disease control: A systematic review. Global Journal of Health Science 2017;10(1):18-35.

18. Ebrahimi Belil F, Alhani F, Ebadi A, Kazemnejad A. Self-Efficacy of People with Chronic Conditions: A Qualitative Directed Content Analysis. J Clin Med. 2018;7(11):411.

19. Razzazan N, Ravanipour M, Gharibi T, Motamed N, Zarei A. Effect of selfmanagement empowering model on the quality of life in adolescents and youths with major thalassemia. J Nurs Educ 2014;3:48-58.

20. Vahedian-azimi A, Alhani F, Goharimogaddam K, Madani S, Naderi A, Hajiesmaeili M. Effect of family-Centered empowerment model on the quality of life in patients with myocardial infarction: A clinical trial study. Iran J Med Educ 2015;4:8-22.

21. Wu SF, Hsieh NC, Lin LJ, Tsai JM. Prediction of self-care behaviour on the basis of knowledge about chronic kidney disease using self-efficacy as a mediator. J Clin Nurs 2016;25(1718):2609-18.

22. Farley H. Promoting self-efficacy in patients with chronic disease beyond traditional education: A literature review. Nurs Open 2019;7(1):30-41.

23. Jones F, Riazi A. Self-Efficacy and selfmanagement after stroke: A systematic review. Disability and Rehabilitation 2011; 33:797-810.

24. Newbold J, Taylor D, Bury M. Lay-led selfmanagement in chronic illness: a review of the evidence. Chronic Illness 2006;2:249-261.

25. Merluzzi TV, Philip EJ, Heitzmann Ruhf CA, Liu H, Yang M, Conley CC. Self-efficacy for coping with cancer: Revision of the Cancer Behavior Inventory (Version 3.0). Psychol Assess 2018;30(4):486-499.

26. Noruzi Zamenjani M, Masmouei B, Harorani M, Ghafarzadegan R, Davodabady F, Zahedi S, et al,. The effect of progressive muscle relaxation on cancer patients' self-efficacy. 
Complementary Therapies in Clinical Practice 2019;34:70-75.

27. Porter LS, Keefe FJ, Garst J, McBride CM, Baucom D. Self-efficacy for managing pain, symptoms, and function in patients with lung cancer and their informal caregivers: Associations with symptoms \& distress. Pain 2008;132(2):306-315.

28. Topçu S, Oğuz S. İnme sonrası self-efficacy ve yaşam kalitesi. Journal of Human Sciences 2017;14(2):1388-1396.

29. Ceyhan YŞ, Ünsal A. Farklı Kronik Hastalığı Olan Bireylerin Öz-Etkililik Düzeylerinin Karşılaştırılması. Dokuz Eylül Üniversitesi Hemşirelik Fakültesi Elektronik Dergisi 2018:11(4).

30. Om Ibrahim Ali Elmelegyl Nagafa Hafez El Mahdy2 Hend Mohamed Elazazy1. Application of the Health Belief Model -Based Educational Intervention on Hand Hygiene Performance of Intensive Care Units' Nurses. Journal of Health, Medicine and Nursing 2018;47:11-24

31. Yılmaz Ü. Akciğer kanserlerinde tedavi yaklaşımları. Nuclear Medicine Semin 2018; 4:32-38.

32. Kirkevold $M$. The role of nursing in the rehabilitation of stroke survivors: an extended theoretical account. Advances in Nursing Science 2010;33(1):E27-E40

33. Çevik Ü. Astımlı çocuk ve adölesanlara verilen eğitimin öz-etkililik ve hastalığın seyrine etkisi. Hemşirelik Programı Yayınlanmamış Doktora Tezi, Atatürk Üniversitesi Sağlık Bilimleri Enstitüsü. Erzurum, Türkiye 2011:19-21.

34. Lam WW, Fielding R. Is self-efficacy a predictor of short-term post-surgical adjustment among Chinese women with breast cancer? Psycooncology 2007;16(7):651-9.

35. Akin S, Can G, Durna Z, Aydiner A. The quality of life and self-efficacy of Turkish breast cancer patients undergoing chemotherapy. European Journal of Oncology Nursing 2008;12(5):449456

36. Özkaraman A, Uzgor F, Dugum Ö, Peker Ş.The Effect of Health Literacy on Self-Efficacy and Quality of Life Among Turkish Cancer Patients J Pak Med Assoc 2019;69(7):995-999.

37. Liang S-Y, Chao T-C, Tseng L-M, Tsay S-L, Lin K-C, Tung H-H. Symptom-Management Self efficacy Mediates the Effects of Symptom Distress on the Quality of Life Among Taiwanese Oncology Outpatients With Breast Cancer. Cancer Nurs 2016;39(1):67-73

38. Lam WW, Fielding R. Is self-efficacy a predictor of short-term post-surgical adjustment among Chinese women with breast cancer? Psycooncology 2007;16(7):651-9.

39. Fan G, Filipczak L, Chow E. Symptom clusters in cancer patients: A review of the literature. Current Oncology 2007;14(5):173-179.
40. Clark JA, Talcott JA. Symptom indexes to assess outcomes of treatment for early prostate cancer. Medical Care 2001;39(10):1118-1130.

41. Chen Hong-Lin, Liu K, Qing-Sheng You. Selfefficacy, Cancer-Related Fatigue, and Quality of Life in Patients With Resected Lung Cancer. Eur J Cancer Care 2018;27(6):e12934.

42. Chirico, A, Lucidi F, Merluzzi T, Alivernini, F, De Laurentiis M, Botti G, et al. A meta-analytic review of the relationship of cancer coping selfefficacy with distress and quality of life. Oncotarget 2017;8(22):36800-36811

43. Adams RN, Mosher CE, Cohee AA, Stump TE, Monahan PO, Sledge GW, et al. Avoidant coping and self-efficacy mediate relationships between perceived social constraints and symptoms among long-term breast cancer survivors. Psycho-Oncology 2016.

44. Liang S-Y, Chao T-C, Tseng L-M, Tsay S-L, Lin K-C, Tung H-H. Symptom-Management Self efficacy Mediates the Effects of Symptom Distress on the Quality of Life Among Taiwanese Oncology Outpatients With Breast Cancer. Cancer Nurs 2016;39(1):67-73.

45. Nejad ZK, Aghdam AM, Hassankhani H, Jafarabadi MA, Sanaat Z. Cancer-Related SelfEfficacy in Iranian Women With Breast Cancer. Women. Health. Bull 2015;2(2): e23248.

46. Liang S, Wu W, Kuo C, Lu Y. Development and Preliminary Evaluation of Psychometric Properties of Symptom-Management SelfEfficacy Scale for Breast Cancer Related to Chemotherapy. Asian Nursing Research 2015:312-317.

47. Zhang Y, Kwekkeboom K, Petrini M. Uncertainty, Self-efficacy, and Self-care Behavior in Patients With Breast Cancer Undergoing Chemotherapy in China. Cancer Nurs 2015;38(3):19-26.

48. Chang H-J, Chen W-X, Lin EC-L, Tung Y-Y, Fetzer S, Lin M-F. Delay in seeking medical evaluations and predictors of self-efficacy among women with newly diagnosed breast cancer: A longitudinal study. Int J Nurs Stud 2014;51(7):1036-47.

49. Shelby RA, Edmond SN, Wren AA, Keefe FJ, Peppercorn JM, Marcom PK, et al. Self-efficacy for coping with symptoms moderates the relationship between physical symptoms and well-being in breast cancer survivors taking adjuvant endocrine therapy. Support Care Cancer 2014;22(10):2851-9.

50. Griggs JJ, Liu Y, Sorbero ME, Jagielski CH, Maly RC. Adjuvant chemotherapy dosing in low-income women: the impact of Hispanic ethnicity and patient self-efficacy. Breast Cancer Res Treat 2014;144(3):665-72

51. García-Jimenez M, Santoyo-Olsson J, Ortiz C, Lahiff M, Sokal-Gutierrez K, Nápoles AM. Acculturation, inner peace, cancer self-efficacy, 
and self-rated health among Latina breast cancer survivors. J Health Care Poor Underserved 2014;25(4):1586.

52. Melchior H, Buscher C, Thorenz A, Grochocka A, Koch U, Watzke B. Self-efficacy and fear of cancer progression during the year following diagnosis of breast cancer. Psycho-Oncology 2013;22(1):39-45.

53. Champion VL, Ziner KW, Monahan PO, Stump TE, Cella D, Smith LG, et al., editors. Development and psychometric testing of a breast cancer survivor self-efficacy scale. Oncol Nurs Forum 2013;40(6):403-10.

54. Ziner KW, Sledge GW, Bell CJ, Johns S, Miller $\mathrm{KD}$, Champion VL, editors. Predicting fear of breast cancer recurrence and self-efficacy in survivors by age at diagnosis. Oncol Nurs Forum 2012;39(3),287-95.

55. Lam A, Secord S, Butler K, Hofer SO, Liu E, Metcalfe KA, et al. A breast reconstruction needs assessment: How does self-efficacy affect information access and preferences? Can J Plast Surg 2012;20(1):37.

56. Rottmann N, Dalton SO, Christensen J, Frederiksen K, Johansen C. Self-efficacy, adjustment style and well-being in breast cancer patients: a longitudinal study. Qual Life Res 2010;19(6):827-36.

57. Mosher CE, Duhamel KN, Egert J, Smith MY. Self-efficacy for coping with cancer in a multiethnic sample of breast cancer patients: associations with barriers to pain management and distress. Clin J Pain 2010;26(3):227-34. 